\title{
THE EFFECTIVENESS OF THE BLENDED LEARNING MODEL ON THE STUDENTS' CRITICAL THINKING SKILLS AND LEARNING MOTIVATION IN ACCOUNTING DEPARTMENT
}

\author{
Della Fadhilatunnisa ${ }^{1}$, Rosidah ${ }^{2}$, M. Miftach Fakhri ${ }^{3}$ \\ ${ }^{1}$ Universitas Islam Negeri Alauddin Makassar, 2,3Universitas Negeri Makassar \\ ${ }_{1}^{1}$ Jalan H. M. Yasin Limpo No. 36 Samata-Gowa, 2,3Jalan A. P. Pettarani, Tidung, Makassar \\ Email: della.fadhilatunisa@uin-alauddin.ac.id ${ }^{1}$, rosidah@unm.ac.id² ${ }^{2}$, fakhri.miftach@gmail.com ${ }^{3}$
}

\begin{abstract}
:
The accountant profession in the 21st century requires good critical thinking skills so that developing the skills needed in the 21st century is necessary in the accounting student' learning environment. Therefore, the technology can be used as a medium for learning and communication between the students and the lecturers. In addition, the problem based learning model as a learning that requires the students to actively participate in each learning to develop the critical thinking skills so that the integration between problem-based face-to-face learning and learning utilizing technology in e-learning media is expected to improve the students' critical thinking skills and the learning motivation. The research aims to: (1) find out the implementation of an effective blended learning model towards the students' critical thinking skills and the learning motivation, and (2) to find out the difference in the students' critical thinking skills and the learning motivation between the experimental class and the control class. This research is a quasi experimental research with non equivalent control group design. The study used one experimental group and one control group. The population in this study was the students who took introductory courses in accounting and accounting information systems so that the samples were taken by using purposive sampling technique. The instruments used are the essay test for the critical thinking skills and the questionnaire for the learning motivation. The data analysis techniques used are paired sample $t$ test and independent sample t test assisted by SPSS 26.00. The findings show that: (1) the results of the paired simple $t$ test show that the implementation of the blended learning model effectively improve the students' critical thinking skills and the learning motivation, and (2) The results of the independent simple $t$ test show that the students' critical thinking skills and the learning motivation of the experimental class have a significant difference with the students of the control class.
\end{abstract}

\begin{abstract}
Abstrak:
Profesi akuntan pada abad 21 membutuhkan keterampilan berpikir kritis yang baik sehingga diperlukan lingkungan belajar mahasiswa akuntansi yang mampu mengembangkan keterampilan yang dibutuhkan di abad 21. Oleh karena itu, teknologi dapat dimanfaatkan sebagai media untuk belajar dan komunikasi antara mahasiswa dan dosen. Selain itu, model problem based learning sebagai pembelajaran yang menuntut mahasiswa berpartisipasi aktif dalam setiap pembelajaran untuk mengembangkan keterampilan berpikir kritisnya sehingga integrasi antara pembelajaran tatap muka berbasis problem based learning dengan pembelajaran yang memanfaatkan teknologi di media e-learning diharapkan dapat meningkatkan keterampilan berpikir kritis dan motivasi belajar mahasiswa. Adapun penelitian ini bertujuan untuk: (1) mengetahui implementasi model blended learning yang efektif terhadap keterampilan berpikir kritis dan motivasi belajar mahasiswa, (2) mengetahui perbedaan keterampilan berpikir kritis dan motivasi
\end{abstract}


belajar mahasiswa antara kelas eksperimen dengan kelas control. Penelitian ini merupakan quasi experimental dengan desain non equivalent control group design. Penelitian ini menggunakan satu kelompok eksperimen dan satu kelompok kontrol. Populasi pada penelitian ini adalah mahasiswa yang mengambil mata kuliah pengantar akuntansi dan sistem informasi akuntansi sehingga sampel diambil secara purposive sampling. Teknik pengumpulan data untuk keterampilan berpikir kritis adalah tes sedangkan untuk motivasi belajar menggunakan angket. Teknik analisis data yang digunakan adalah paired sample $t$ test dan independent sample $t$ test dengan bantuan SPSS 26.00. Hasil penelitian menunjukkan: (1) Hasil uji paired simple $t$ test menunjukkan implementasi dari model blended learning secara efektif meningkatkan keterampilan berpikir kritis dan motivasi belajar mahasiswa, (2) Hasil uji independent simple $t$ test menunjukkan keterampilan berpikir kritis dan motivasi belajar mahasiswa kelas eksperimen memiliki perbedaan secara signifikan dengan mahasiswa kelas kontrol.

\author{
Keywords: \\ Blended Learning Model, Problem Based Learning, Critical Thinking Skills, Learning \\ Motivation.
}

How to Cite: Fadhilatunisa, D., Rosidah \& Fakhri, M. M. (2020). The Effective of The Blended Learning Model on The Students' Critical Thinking Skills and Learning Motivation in Accounting Departement. Lentera Pendidikan : Jurnal Ilmu Tarbiyah dan Keguruan, 23(2), 194-208. https://doi.org/10.24252/lp.2020v23n2i1.

\title{
INTRODUCTION
}

The presence of industrial revolution 4.0 is characterized by the increasing need for jobs by utilizing information technology that is the process of automation, digitization, and digital transformation. This condition certainly has an impact on almost all types of work including on the scope of work in the field of accounting. The accounting profession is predicted to decrease by $26 \%$ in 2022 as a result of automation (World Economic Forum, 2018). An accountant is expected to focus on developing not only hard skills but also the soft skills as the support to compete in the 21st century. The competencies required by accountants to be able to compete in these conditions are: (1) Attention to detail and data analytics skills, (2) Team Player, (3) Effective Communication Skills, (4) Leadership, and (5) Creativity (Singapore Accountancy Commission, 2017). Therefore, higher education has an important role to prepare students with hard skills and soft skills that can be professionally required in the era of the competitive industrial revolution 4.0. Higher education as an institution that prepares human resources (HR) that has quality competencies requires strategies in its learning process to achieve the expected learning outcomes. The strategy that can be done in achieving it is by adopting the concept of outcome-based education (OBE). OBE emphasizes the learning process implemented innovatively, interactively, and effectively. The characteristics of OBE are learning that makes students as its center (student-centered learning) and flexibility (anywhere and anytime). E-learning is a learning medium with a high level of flexibility 
and can be utilized by students as a means of learning and communication between lecturers and students.

E-learning is a popular learning medium that can meet continuous changes in learning (Shilwant \& Haggarty, 2005).The existence of e-learning in higher education is utilized as a supplement to the learning environment in face-to-face classes (Tetiwat, 0. ., \& Igbaria, 2000). Besides, e-learning on mobile devices helps students in the learning process with no restrictions on learning locations (Lam, Yau, \& Cheung, 2010). However, face-to-face learning and e-learning still have limitations on for the learners. This condition can be seen in higher education students who are less satisfied with learning with the help of e-learning media than face-to-face learning (Nces, 2008). According to Cai \& Yao (2010), in the learning process with e-learning media, the students tend to have low motivation. In addition, the teacher-centered learning has an impact on students who tend to be passive during the learning process (Dabbagh \& Bannan, 2005).

Strategies that can be done to overcome weaknesses in face-to-face learning and online learning with e-learning media can be done by integrating both concepts of learning or known as blended learning models. The blended learning model is learning that integrates positive aspects of learning activities synchronously (virtual and direct) with asynchronous (collaborative and independent) learning activities (Howard, Remenyi, \& Pap, 2006 ; Thorne, 2003). Blended learning has the main goal of providing stimulus to students to use as much as possible face-to-face meetings in the classroom with knowledge in e-learning (W. D. Dwiyogo, 2018). The benefits of blended learning to the maximum are expected to maximize the potential of students with the flexibility and innovative found in the blended learning.

The benefits of blended learning models are also shown in the research findings by Tsai \& Tang (2017); Yu, Lin, Ho, \& Wang (2015) which indicate that the implementation of blended learning shows positive results on problem-solving skills and the improvement is more significant compared to the traditional learning and has a positive impact on the stability of learning achievement. Similar results were also found by Maryana \& Abriano (2017) who explaine that the blended learning model affects the learning outcomes of accounting and management courses. The benefits of blended learning models for employability skills are demonstrated by the research from Lane (2016) which showed that the development of the student employability skills can be done with a combination of traditional learning with online or so-called blended learning. Referring to the above studies it can be assumed that the implementation of blended learning can be beneficial for student competencies. The implementation of blended learning models with the help of Edmodo Learning Management System (LMS) technology is expected to help in improving the students' critical thinking skills. LMS Edmodo is expected to be an opportunity for students to build teamwork to develop critical thinking skills (Al-Kathiri, 2015). In addition, Al-Said (2015) explained that the students have high motivation during the learning assisted by LMS Edmodo and can effectively help the students to communicate. 
Critical thinking skills as the skills needed in the 21st century (Singapore Accountancy Commission, 2017) can be developed with the help of blended learning models. The integration of Edmodo's LMS-based synchronous and asynchronous learning is expected to help improve the critical thinking skills of accounting students. LMS Edmodo is a learning medium with the concept of social networking with a view or interface that has the same concept as Facebook so that the students are expected to be more active during the learning process in e-learning media. Blended learning-based learning applications are expected to help improve critical thinking skills and motivation to learn students in the classroom. Therefore, the blended learning model as a learning centered on students as a focus contains learning principles centered on students according to the American Psychological Association (1997) namely: (1) a learning environment influenced by technology, and (2) a learning model that helps the students to develop high-level thinking skills characterized by the students who are able to produce solutions to problems faced during the learning process.

Based on the above description, the implementation of this blended learning model is expected to help higher education students, especially accounting students, develop critical thinking skills and improve the students' learning motivation during face-to-face and online learning. The combination of face-to-face learning based on problem based learning model with LMS-based online learning Edmodo is expected to help students in the process of identifying problems, conducting discussions with lecturers and friends in the classroom and LMS edmodo as well as solving problems provided by the lecturers. The purpose of this research is to find out the effectiveness of the blended learning model towards critical thinking skills and motivation of the accounting students as well as the differences in critical thinking skills and learning motivation between the students with blended learning experience with the students with conventional learning model.

\section{RESEARCH METHOD}

This research was conducted in the Accounting Department of the Faculty of Economics and Islamic Business of Alauddin State Islamic University of Makassar (UINAM). The population in this study was the students who studied accounting information system courses. The sampling technique used is purposive sampling technique which is a sampling technique taking into account certain conditions.

Table 1. Number of Research Samples

\begin{tabular}{cccc}
\hline Subject & Experimental Class & Control Class & Total \\
\hline Accounting Information System & 35 & 34 & 69 \\
\hline
\end{tabular}

This study is a quasi-experimental approach in which the study subject is not randomly selected. Researchers used Nonequivalent Control Group Design as the research design involving experimental groups and control groups. The students in the experimental group gained a blended learning experience combined with problem-based problem-based learning with edmodo LMS-based online learning. In problem-based faceto-face learning, lecturers as educators oriented the problems related to the materials 
that had been given to the students at LMS edmodo. The process of resolving this problem was carried out in groups that had been shared by the lecturers. The role of lecturers in blended learning as the guides on the stage was the guide in the problem solving process where lecturers provided facilities in the form of teaching materials and rapid response related to the questions from the students, while learning in the control group used traditional learning.

The instruments used are the essay test for the critical thinking skills and the questionnaire for the learning motivation. the critical thinking skills essay test sheets and motivational learning questionnaire sheets were shared before and after the treatment of learning models in experimental group and control group. This is done to find out the benefits of blended learning models towards the improvement of the critical thinking skills and the students' learning motivation.

The data of the students' critical thinking skills and the learning motivation from the experimental group and control group were analyzed by using descriptive analysis and inferential analysis. Both analyses were assisted by SPSS 26.00 software. Descriptive analysis that describes critical thinking skills and the students' learning motivation in both groups can be seen on the mean scores. As for inferential analysis data of critical thinking skills and learning motivation that had been obtained were analyzed with the $t$ test namely paired-sample t-test and independent-sample t-test, but before that, it was conducted the classic assumption test as a condition of the conduct of both tests consisting of normality test with Sapphiro Wilk and homogeneity test with Levene test. The requirement that the data are categorized meet the normal and homogeneous criteria if the significant value is more than 0.05 .

The data analysis technique with paired sample t-test is to find out the effectiveness of blended learning model and independent-sample t-test to find out the difference in critical thinking skills and learning motivation between the experimental group and the control group.

\section{RESULTS AND DISCUSSION}

The inferential statistical analysis can be performed after qualifying from the classic assumption test which is the test of normality and homogeneity. Normality test results on the students' critical thinking skills data of the experimental group and control group as follows.

Table 2. Data Normality of Critical Thinking Skills

Tests of Normality

\begin{tabular}{ll|r|r|r} 
Kelas & & \multicolumn{1}{c}{ Statistic } & \multicolumn{1}{c}{ Df } & \multicolumn{1}{c}{ Sig. } \\
\hline Pre-test & Experimental Class & .942 & 35 & .062 \\
\cline { 2 - 6 } & Control Class & .966 & 34 & .353 \\
\hline \multirow{2}{*}{ Post-test } & Experimental Class & .964 & 35 & .303 \\
\cline { 2 - 6 } & Control Class & .963 & 34 & .292 \\
\hline
\end{tabular}

Source: Output SPSS 
Table 2 shows that the sig. value of critical thinking skills for the experimental group in both pre-test and post-test is greater than 0.05 so it can be assumed that the data of the experimental group obtained is distributed normally. Then the sig. value of the critical thinking skills of the control group on pre-test and post-test has a greater value as well than 0.05 so it can also be concluded that the control group data is distributed normally. The normality test results in the data of the research findings of the students' learning motivation in the experimental group and control group as follows.

Table 3. Data Normality of Learning Motivation

\section{Tests of Normality}

\begin{tabular}{l|l|r|r|r} 
Kelas & & Statistic & df & Sig. \\
\hline \multirow{2}{*}{ Early } & Experimental Class & .958 & 35 & .198 \\
\cline { 2 - 5 } & Control Class & .974 & 34 & .575 \\
\hline \multirow{2}{*}{ End } & Experimental Class & .957 & 35 & .180 \\
\cline { 2 - 5 } & Control Class & .981 & 34 & .801 \\
\hline
\end{tabular}

Source: Output SPSS

Table 3 shows that the sig. value of the students' learning motivation in the experimental group in both pre-test and post-test is greater than 0.05 so it can be assumed that the data of the experimental group obtained is distributed normally. Then the sig. motivation score of the control group in the pre-test and post-test has a greater value as well than 0.05 so it can also be concluded that the control group data is distributed normally. The next assumption test result discussed is a homogeneity test. Table 4 shows the homogeneity test results for the critical thinking skills data.

Table 4. Critical Thinking Skills Homogeneity Data

Homogeneity Test of Variance

\begin{tabular}{llrlrr|r} 
& & Levene Statistic & df1 & df2 & Sig. \\
\hline Pre-test & Based on Mean & .067 & 1 & 67 & .797 \\
\hline Post-test & Based on Mean & .224 & 1 & 67 & .637 \\
\hline
\end{tabular}

Source: Output SPSS

Based on table 4, the result of the sig. value in the pre-test is 0.797 , and the sig. value in the post-test is 0.637 which indicate that the sig. value in both indicators is greater than 0.05 . This suggests that the data are in homogeneous categories or variations of the critical thinking skills data have the same variance. The homogeneity test results for learning motivation data are described in table 5 below. 
Table 5. Learning Motivation Homogeneity Data

\begin{tabular}{llr|r|r|r}
\multicolumn{2}{c}{$\begin{array}{c}\text { Homogeneity Test of Variance } \\
\text { Levene Statistic }\end{array}$} & df1 & df2 & Sig. \\
\hline Early & Based on Mean & .070 & 1 & 67 & .793 \\
\hline End & Based on Mean & 1.463 & 1 & 67 & .231 \\
\hline
\end{tabular}

Source: Output SPSS

Based on table 5, the result that the sig value in the pre-test is 0.793 , and the sig value in the post-test is 0.231 which indicates that the sig value in both indicators is greater than 0.05 . it indicates that the data are in a homogeneous category or variations of the learning motivation data have the same variance. After the fulfillment of the requirements on the classic assumption test, the paired-sample t-test can be conducted to measure the effectiveness of the blended learning model against the critical thinking skills and the students' learning motivation, as well as an independent sample t-test to find out the difference in the critical thinking skills and the students' learning motivation with blended learning model in the experimental class students with conventional learning model.

\section{The Effectiveness of Blended Learning Model on the Critical Thinking Skills and the Students' Learning Motivation}

The results of descriptive statistical analysis show that there is an improvement in the critical thinking skills of the students in the experimental group after the implementation of blended learning. This is indicated by the mean score before and after blended learning implementation in the following table 6 .

Table 6. Data Descriptive Analysis of the Critical Thinking Skills of the Experimental Group

\section{Paired Samples Statistics}

\begin{tabular}{|c|c|c|c|c|c|}
\hline & & Mean & $\mathbf{N}$ & $\begin{array}{c}\text { Std. } \\
\text { Deviation }\end{array}$ & $\begin{array}{c}\text { Std. Error } \\
\text { Mean }\end{array}$ \\
\hline \multirow[t]{2}{*}{ Pair 1} & Pre-test & 49.89 & 35 & 6.876 & 1.162 \\
\hline & Post-test & 72.74 & 35 & 6.363 & 1.076 \\
\hline
\end{tabular}

Source: Output SPSS

Table 6 above shows that the post-test average is 72.74 which is higher than the pre-test average of 49.89. it means that there is an increase in the students' critical thinking skills in the experimental group. However, to know the significance of improving the critical thinking skills and the effectiveness of the blended learning model, the pairedsample t-test was used as shown in the following table 7. 
Table 7. Data Results of Paired sample t-test of the Critical Thinking Skills

\section{Paired Samples Test}

\begin{tabular}{|c|c|c|c|c|c|c|c|}
\hline & & Pai & ed Samples & est & & & \\
\hline & & & Paire & Differences & & & \\
\hline & & Mean & $\begin{array}{c}\text { Std. } \\
\text { Deviation }\end{array}$ & $\begin{array}{c}\text { Std. Error } \\
\text { Mean }\end{array}$ & $\mathbf{T}$ & df & $\begin{array}{l}\text { Sig. (2- } \\
\text { tailed) }\end{array}$ \\
\hline Pair 1 & Post-test - Pre-test & $\begin{array}{c}22.85 \\
7\end{array}$ & 5.117 & .865 & 26.426 & $\begin{array}{l}3 \\
4\end{array}$ & .000 \\
\hline
\end{tabular}

Source: Output SPSS

Table 7 indicates that the sig value is less than 0.05 and the $t$-count value is more than the t-table. Therefore, the application of blended learning models is effective in improving the students' critical thinking skills. As for the motivation of student learning shows that after the implementation of blended learning, the motivation of learning students of the experimental group increase from the previous one. It is shown in table 8 below.

Table 8. Data Descriptive Analysis of the Learning Motivation of the Experimental Group

\section{Paired Samples Statistics}

\begin{tabular}{ll|r|r|r|r} 
& & & \multicolumn{1}{c|}{$\begin{array}{c}\text { Std. } \\
\text { Mean }\end{array}$} & N & \multicolumn{2}{c}{$\begin{array}{c}\text { Std. Error } \\
\text { Deviation }\end{array}$} & \multicolumn{1}{c}{ Mean } \\
\hline Pair 1 & Early & 57.71 & 35 & 6.285 & .947 \\
\cline { 2 - 6 } & End & 69.03 & 35 & 5.602 & 1.062 \\
\hline
\end{tabular}

Source: Output SPSS

Table 8 above shows that the average final score of the learning motivation is 68.96 which is higher than the average final score of the learning motivation of 57.71. it means that there is an increase in the students' learning motivation in the experimental group. However, to know the significant improvement of the students' learning motivation and the effectiveness of the blended learning model are tested by using the paired-sample $t$ test which is shown in the following table 9.

Table 9. Data Results of Paired sample t-test of the Learning Motivation

Paired Samples Test

\begin{tabular}{|c|c|c|c|c|c|c|c|}
\hline \multicolumn{8}{|c|}{ Paired Samples Test } \\
\hline & & \multicolumn{6}{|c|}{ Paired Differences } \\
\hline & & Mean & $\begin{array}{c}\text { Std. } \\
\text { Deviation }\end{array}$ & Std. Error Mean & $\mathbf{T}$ & df & $\begin{array}{l}\text { Sig. (2- } \\
\text { tailed) }\end{array}$ \\
\hline Pair 1 & End-Early & 11.314 & 5.144 & .869 & 13.013 & 34 & .000 \\
\hline
\end{tabular}

Source: Output SPSS

Table 9 shows that the sig. value is less than 0.05 and the $t$-count value is more $t$ table so it can be assumed that the blended learning model is effective in improving the 
students' learning motivation. Based on both test results of paired sample t-test on the students' critical thinking skills and the learning motivation show that the blended learning model is effective in improving the students' critical thinking skills and learning motivation in the experimental group. The overview of improving the students' critical thinking skills learning motivation of the experimental group can be seen in the figure 1 below.

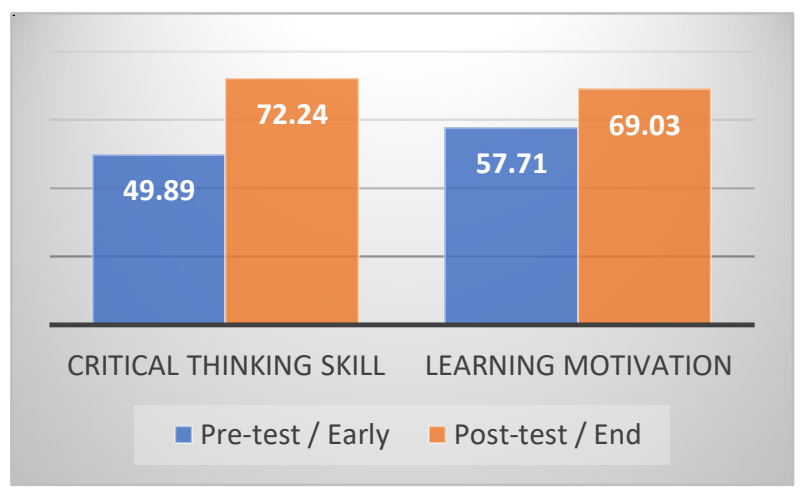

Figure 1. the Average score of the Critical Thinking Skills and Learning Motivation of the Experimental Group Students

The students' critical thinking skills of the experimental group with the blended learning activities improved and had a more positive difference compared to the control group with traditional or conventional learning. The blended learning models are implemented synchronously or directly problem-based and asynchronous collaboratively and independently. The benefit of collaborative asynchronous learning is that the students can interact with each other or share knowledge about courses so that the students can have good science and can be used as a provision to be able to discuss in the classroom. The combination of problem-based live events with Edmodo LMS-based online learning can also assist students in improving the ability to interpret information obtained where information has been interpreted. Furthermore, this information can be used in drawing conclusions and categorizing or classifying information obtained to solve problems encountered during the learning process. The implementation of blended learning in improving the students' critical thinking skills is also explained by Tarunasena (2017); Deechai, Sovajassatakul, \& Petsangsri (2019) who suggest that the blended learning encourages the students to study together outside the classroom in the medium of e-learning and ensures that face-to-face learning time can be utilized to develop the students' understanding of learning materials and high-level thinking skills, namely the critical thinking skills.

However, the opposite condition is obtained by Akyüz \& Samsa (2009) who explain that the application of blended learning does not improve the students' critical thinking skills. It can be seen in the absence of the significant increase in the post-test compared to the pre-test. This condition is obtained because of the benefits of online learning that does not fully support face-to-face learning where the form of discussion conducted does not support in improving the students' critical thinking skills. It is strengthen by Alotaibi, 
2013 who explains that the blended learning has not had a positive impact in the development of the students' critical thinking skills. It can be seen in the students who are reluctant to participate in the learning with the concept of the blended learning and the lack of the students participation during the discussion. The development of the students' critical thinking skills cannot be achieved to the maximum if all elements of the blended learning do not integrate together in their application. Therefore, the role of the lecturers as the educators is to explain the benefits of the blended learning to the students so that the students have encouragement in the learning process in the classroom as well as in the medium of e-learning.

\section{The Differences in the Students' Critical Thinking Skills and Learning Motivations of the Experimental Group and Control Group}

Differences in the students' critical thinking skills of the experimental group and the control group can be known by conducting independent sample t-tests. Independent sample t-test data for the Critical Thinking Skills can be found in table 10 below.

Table 10. Independent Sample T-test of the Critical Thinking Skills Data

Independent Samples Test

\begin{tabular}{ll|r|r|r|r|} 
& & & \multicolumn{3}{|c|}{ t-test for Equality of Means } \\
& \multicolumn{1}{c|}{ d } & df & Sig. (2-tailed) & Mean Difference \\
\hline Pre-test & Equal variances assumed & -4.412 & 67 & .000 & -7.467 \\
\hline Post-test & Equal variances assumed & 6.453 & 67 & .000 & 9.684 \\
\hline
\end{tabular}

Source: Output SPSS

Based on table 10, the sig. value is less than 0.05 and the $t$-count value is more than the $\mathrm{t}$-table which indicate that there is a significant difference between the critical thinking skills of both groups. Therefore, the students who are taught by the application of blended learning models have better critical thinking skills than the students with conventional learning. Inddition, it can be seen in the early critical thinking skills that the data have a mean difference of $-4,412$ which means the value of the experimental group is lower than the control group, while the final critical thinking skills data have a mean difference of 6.453 which means that the final critical thinking skill score of the experimental group is higher than the control group. Furthermore, the independent sample t-test was conducted to find out if there is a significant difference in learning motivation between the experimental group and the control group as shown in the following Table 11. 
Table 11. Data Results of the Independent sample t-test of the Learning Motivation

Independent Samples Test

\begin{tabular}{ll|r|r|r|r|} 
& & & \multicolumn{3}{|c|}{ t-test for Equality of Means } \\
& & d & df & Sig. (2-tailed) & Mean Difference \\
\hline Pre-test & Equal variances assumed & -2.034 & 67 & .000 & -3.227 \\
\hline Post-test & Equal variances assumed & 2.065 & 67 & .000 & 2.587 \\
\hline
\end{tabular}

Source: Output SPSS

Table 11 shows that the sig. scores obtained are less than 0.05 and the t-count scores are more than t-tables so it can be assumed that the students who follow the blended learning have better motivation than the students who follow conventional learning. Besides, it can be seen in the early learning motivation that it has the mean difference of -2.034 which means that the value of the experimental group is lower than the control group. While the final learning motivation has the mean difference of 2.065 which means that the final learning motivation of the experimental group is higher than the control group. Based on the results of the independent sample t-test on the students' critical thinking skills learning motivation, they show that that students of the experimental group with blended learning models have better critical thinking skills and learning motivation than the control group with conventional learning.

The positive impact of using LMS Edmodo is to increase the learning motivation in the experimental group. The attractiveness and the practicality make it easy for the students to use every feature in Edmodo's LMS. The integration of the blended learning models with LMS Edmodo has a positive impact on improving the learning interests and learning outcomes of the students. It is demonstrated in the active participation of the students in learning at LMS Edmodo which can help the students in the learning process in face-to-face classes Sriwartini, Siswandari, \& Hamidi (2015); Hikmah (2017); Sulistiani \& Sukirno (2016). The blended learning models with adaptive learning environments and high levels of flexibility can help in improving the students' learning motivation by stimulating the students to learn both face-to-face and online (Dankbaar, 2017).

The implementation of the blended learning models has a positive impact on the problem-solving skills. This condition can be seen in the response to each learning activity in the classroom (synchronous directly) to solve problems given by the educators or found by the students themselves (W. Dwiyogo, 2018; Tsai \& Tang, 2017). The contribution of technology as a learning medium helps the students in creating an effective and efficient environment or learning climate. It can be seen in the information or science that is more easily accessible in e-learning media. The students can take advantage of the facilities provided by the lecturers by doing learning wherever and whenever either collaboratively or discussing online or independently (Jou, Lin, \& Wu, 2016). The role of the lecturers in e-learning is as facilitators that provide facilities to the students in the form of e-books, voice notes, and video tutorials as a supplement to students to study at home or study independently. The gained benefit from this activity is 
that the students know they can find solutions to the problems encountered and can synthesize knowledge gained in the classroom with the knowledge gained outside the classroom that can produce ideas that can be utilized to complete every task given by the lecturer, but what needs to be noted is the motivation of the lecturers as the educators and facilitators in blended learning models. The internal and external factors in the lecturers also influence the motivation of lecturers in the learning process (Ibrahim \& Nat, 2019). Therefore, cooperation is needed on various sides so that the motivation and interest of learning both in educators as facilitators increases and the creation of a learning environment both synchronous and asynchronous.

The blended learning model builds a conducive learning environment that can motivate the students to come together or individually to build knowledge and develop their skills. In addition, the blended learning model helps the students develop their reasoning, the integration of synchronous learning and e-learning brings learning that can help students to be more motivated in developing their logical thinking (GiraldoGarcía, Roy, \& Alotebi, 2015). Therefore, cooperation from both the lecturers and the students is needed to create a conducive learning climate by understanding their respective roles in the blended learning (Borglum, 2016).

The concept of the student-centered learning is a learning that can be implemented anytime and anywhere (anywhere) providing accommodation to the learning style of the students in a better or positive direction. The flexibility of information obtained by the students provides the ability to recognize the information needed, analyze, evaluate, and utilize the information to develop their skills in the classroom or the future. This condition can certainly improves the students communication skill because the flexibility of the blended learning can reduce the gap between the students and the educators as instructors and help them to communicate more effectively each other (Sriarunrasmee, Techataweewan, \& Mebusaya, 2015). The blended learning model is a combination of synchronous learning and asynchronous learning expected to provide a real learning experience to the students to develop their skills especially in the critical thinking and communication skills (Shorey, Kowitlawakul, Devi, Chen, \& Shong, 2018).

The presence of the blended learning models in universities, especially in accounting departments is expected to help both elements of the learning process, namely the lecturers as the educators and the students as the learners together to carry out the maximum positive aspects of face-to-face and online learning. Therefore, the achievement of learning both hard skills and soft skills needed by accounting students can be achieved. However, there are still some flaws in the application of the blended learning model such as the limitation of the lecturers as the educators in online learning in shich the lecturers have not been able to utilize every feature in LMS to the maximum. Besides, teaching materials from the lecturers in the form of media video tutorials that are also still very limited that cannot be able to maximize the learning activities of LMS Edmodo well. Therefore, cooperation is needed on the part of higher education institutions to provide the stimulus for the lecturers as the educators to maximize the learning activities and the teaching materials provided. 


\section{CONCLUSION}

Based on the data exposure and the research data analysis results, the researchers conclude that the blended learning model is effective in the process of improving the students' critical thinking skills and the learning motivation. Furthermore, the critical thinking skills and the learning motivation in the experimental group are better than the control group which was taught by using traditional learning. This condition is certainly inseparable from the positive aspects of the blended learning that require the students to play an active role in the learning process both in the classroom (offline) and outside the classroom (online). The combination of the problem-based learning-based face-to-face learning with LMS-based online learning can help the students in the process of developing the critical thinking skills with problem-oriented learning and the lecturers who provide facilities to the students with the teaching materials and motivation during the learning. However, to maximize the expected learning achievements, all elements of higher education institutions both leaders, educators, educational personnel, and the students need to collaboratively implement the blended learning system that has certainly been agreed together.

The suggestion for the lecturers is the presence of the blended learning model is expected to help lecturers as the educators in carrying out their role as the facilitators and motivators in the classroom and it is expected that the lecturers can spend more time studying the positive aspects of the blended learning model to help the students in developing their competencies and talents. Furthermore, for the next researcher, it is expected to develop the implementation of the blended learning model not only on the aspect of employability skills in the critical thinking skills but also conduct the research on other competencies needed by the accounting graduates. Absolutely, the blended learning as a flexible learning can be combined with various methods, models and elearning media based on to its needs so that learning with the blended learning model can be used as the learning alternative in other courses in accounting majors even in all majors of the Faculty of Economics and Islamic Business at Alauddin State Islamic University of makassar.

\section{REFERENCES}

Akyüz, H. I., \& Samsa, S. (2009). The effects of blended learning environment on the critical thinking skills of students. Procedia - Social and Behavioral Sciences, 1(1), 1744-1748. https://doi.org/10.1016/j.sbspro.2009.01.308.

Al-Kathiri, F. (2015). Beyond the classroom walls: Edmodo in saudi secondary school EFL instruction, Attitudes and challenges. English Language Teaching, 8(1), 189-204. https://doi.org/10.5539/elt.v8n1p189.

Al-Said, K. M. (2015). Students' perceptions of edmodo and mobile learning and their real barriers towards them. Turkish Online Journal of Educational Technology, 14(2), 167-180. https://files.eric.ed.gov/fulltext/EJ1057371.pdf.

Alotaibi, K. N. R. (2013). The Effect of Blended Learning on Developing Critical Thinking Skills. Education Journal, 2(4), 176. https://doi.org/10.11648/j.edu.20130204.21 
Association, A. P. (1997). This historical document is derived from a 1990 APA presidential task force (revised in 1997). Alvarez, K., Garofano, C. M. (2004). An Integrat.

Borglum, R. N. (2016). The effects of blended learning on critical thinking in a high school Earth Science class. 68.

Cai, X. ., \& Yao, Y. (2010). The Past and Present Lives of Blended Learning in the Context of Open Universities. In: Au, O., Kong, S.C., Kling, F. (eds.) Hybrid Learning 2.0.

Commission, S. A. (2017). Skills Framework for Accountancy Career Pathways (A Guide to Occcupation and Skills). Singapore Accountancy Commission.

Dabbagh, N., \& B, B.-R. (2005). Online learning: concepts, strategies, and application.

Dankbaar, M. (2017). Serious games and blended learning; effects on performance and motivation in medical education. Perspectives on Medical Education, 6(1), 58-60. https://doi.org/10.1007/s40037-016-0320-2.

Deechai, W., Sovajassatakul, T., \& Petsangsri, S. (2019). The Need for Blended Learning Development to Enhance the Critical Thinking of Thai Vocational Students. Mediterranean Journal of Social Sciences, 10(1), 131-140. https://doi.org/10.2478/mjss-2019-0013.

Dwiyogo, W. (2018). Developing a Blended Learning-Based Method for Problem-Solving in Capability Learning. Tojet - The Turkish Online Journal of Educational Technology, 17(1), 51-61.

Dwiyogo, W. D. (2018). Pembelajaran Berbasis Blended Learning (1st ed.). PT. RajaGrafindo Persada. https://files.eric.ed.gov/fulltext/EJ1165753.pdf.

Giraldo-García, R., Roy, M., \& Alotebi, H. (2015). The Interplay of Technology and Critical Thinking Skills in the 21st Century Blended Classroom. International Journal of Advanced Research, 2(3),

2(3), 4 https://www.researchgate.net/publication/321934531_The_Interplay_of_Techn ology_and_Critical_Thinking_Skills_in_the_21st_Century_Blended_Classroom.

Hikmah, N. (2017). Efektivitas Media Pembelajaran Edmodo Terhadap Minat Belajar Siswa dan Hasil Belajar Siswa Pada Materi Fisika di Kelas XI IPA SMAN 1 Tanete Rilau.

Howard, L., Remenyi, Z., \& Pap, G. (2006). Adaptive blended learning environments. International Conference On, 23-28. https://www.researchgate.net/publication/235972772_Adaptive_Blended_Learn ing_Environments.

Ibrahim, M. M., \& Nat, M. (2019). Blended learning motivation model for instructors in higher education institutions. International Journal of Educational Technology in Higher Education, 16(1). https://doi.org/10.1186/s41239-019-0145-2.

Jou, M., Lin, Y. T., \& Wu, D. W. (2016). Effect of a blended learning environment on student critical thinking and knowledge transformation. Interactive Learning Environments, 24(6), 1131-1147. https://doi.org/10.1080/10494820.2014.961485.

Lam, J., Yau, J., \& Cheung, S. K. S. (2010). A review of mobile learning in the mobile age. Lecture Notes in Computer Science (Including Subseries Lecture Notes in Artificial Intelligence and Lecture Notes in Bioinformatics), 6248 LNCS, 306-315. https://doi.org/10.1007/978-3-642-14657-2_28.

Lane, S. (2016). Developing Employability Skills by Using Blended Learning. American Journal of Educational Research, 4(1), 47-53. https://doi.org/10.12691/education-4-1-9. 
Makmur, T. (2017). Blended Learning Model Implementation To Improve Critical Thinking Skill in History Learning. Historia: Jurnal Pendidik Dan Peneliti Sejarah, 13(2), 153. https://doi.org/10.17509/historia.v13i2.6207.

Maryana, F., \& Abriano, N. (2017). Pengaruh Metode Pembelajaran Blended Learning Terhadap Hasil Capaian Pembelajaran Mahasiswa Program Studi Akuntansi Dan Manajemen Pada Perguruan Tinggi Swasta Di Banjarmasin. 14.

Nces, E. (2008). Postsecondary Education Descriptive Analysis Report. Education, NCES 2007-162. https://nces.ed.gov/pubsearch/getpubcats.asp?sid=017.

Shilwant, S., \& Haggarty, A. (2005). Usability testing for e-learning. Issue of Chief Learning Officer Magazine, 4-7. https://elearnmag.acm.org/archive.cfm?aid=1373284\#.

Shorey, S., Kowitlawakul, Y., Devi, M. K., Chen, H. C., Soong, S. K. A., \& Ang, E. (2018). Blended learning pedagogy designed for communication module among undergraduate nursing students: A quasi-experimental study. Nurse Education Today, 61, 120-126. https://doi.org/10.1016/j.nedt.2017.11.011.

Sriarunrasmee, J., Techataweewan, W., \& Mebusaya, R. P. (2015). Blended Learning Supporting Self-Directed Learning and Communication Skills of Srinakharinwirot University's First Year Students. Procedia - Social and Behavioral Sciences, 197, 1564-1569. https://doi.org/10.1016/j.sbspro.2015.07.111.

Sriwartini, D., Siswandari, S., \& Hamidi, N. (2015). Strategi Meningkatkan Hasil Belajar Akuntansi Melalui Metode Blended Learning Berbasis Edmodo Social Networking. Seminar Nasional Pendidikan Akuntansi Dan Keuangan, 167-177. https://www.neliti.com/id/publications/171438/strategi-meningkatkan-hasilbelajar-akuntansi-melalui-metode-blended-learning-be.

Sulistiani, F., \& Sukirno, S. (2016). the Implementation of Blended Learning Model Based on Edmodo To Improve Students' Learning Motivation and Achievement. Jurnal Pendidikan Akuntansi Indonesia, https://doi.org/10.21831/jpai.v14i1.11371.

Tetiwat, 0., \& Igbaria, M. (2000). Opportunities in Web-based teaching: The future of education. In Web-based learning and teaching technologies: Opportunities and challenges. Idea Group Publishing. https://doi.org/0.4018/978-1-878289-605.ch002.

Thorne, K. (2003). Blended learning [electronic resource]: how to integrate online \& traditional learning. Kogan Page.

Tsai, M. H., \& Tang, Y. C. (2017). Learning attitudes and problem-solving attitudes for blended problem-based learning. Library Hi Tech, 35(4), 615-628. https://doi.org/10.1108/LHT-06-2017-0102.

World Economic Forum. (2018). The Future of Jobs Report 2018 | World Economic Forum. In Research Report (Issue January, p. 135).

Yu, W. C. W., Lin, C. C., Ho, M. H., \& Wang, J. (2015). Technology facilitated PBL pedagogy and its impact on nursing student's academic achievement and critical thinking dispositions. Turkish Online Journal of Educational Technology, 14(1), 97-107. https://files.eric.ed.gov/fulltext/EJ1057343.pdf. 